\title{
WORKING EFFICIENCY OF REINFORCED CONCRETE BAY BRIDGE STRUCTURES WITH CORROSIVE DEFECTS CONCRETE AND STEEL REINFORCEMENT
}

Sergey Emelyanov

Ekaterina Pakhomova ${ }^{2}$

Natalya Semicheva ${ }^{3}$

UDK: 624.21.012.45:620.193

DOI: $10.14415 /$ konferencijaGFS2019.004

Abstract: The paper presents an analysis of corrosion processes and identifies main causes of durability loss in operating reinforced concrete bridges. The paper also discusses some methods used to assess the reinforcement corrosion rates in reinforced concrete structures of motorway bridges.

Key words: reliability, reinforced concrete bridges, reinforcement corrosion

\section{INTRODUCTION}

To increase the reliability and longevity of reinforced concrete bridges is a pending, complex and multiple-factor problem that can be solved only if its various aspects are considered in detail. One of the most essential parts of this problem is the analysis of processes that run in a reinforced concrete structures under environmental impacts and reduce their longevity.

To maintain appropriate operational condition of reinforced concrete motorway bridges is vitally important for normal functioning of a national infrastructure in any developed country and is a challenge to be met at a governmental level.

According to the World Bank about 30\% of more than 60000 motorway bridges in Russia are in an inappropriate condition because of different defects and about $1 \%$ of motorway bridges collapse annually. Lately the possibilities of increasing the life time of reinforced concrete motorway bridges have been in the research interest focus. First of all this is explained by unsatisfactory condition of many reinforced concrete bridges that reach a critical dilapidation degree after 30-40 years of operation.

\footnotetext{
${ }^{1}$, Sergey Emelyanov, Doctor of Engineering, Professor, Rector of the Southwest State University, 50 years of October 94 st.,, Kursk, Russia, tel: +7 (4712) 50-48-00, e - mail: rector @ swsu.ru

${ }^{2}$ Ekaterina Pakhomova, Candidate of Engineering, Associate Professor, Dean of the Faculty of Civil Engineering and Architecture, Southwest State University, Faculty of Civil Engineering and Architecture, 50 years of October st., 94, Kursk, Russia, tel: + 790387734 69, e - mail: egpakhomova@ yandex.ru

${ }_{3}^{3}$ Natalia Semicheva, Candidate of Engineering, Associate Professor, Southwest State University, Faculty of Engineering and Architecture, 50 years of October 94 st.,, Kursk, Russia, tel: + 790387734 69, e - mail: nsemicheva@yandex.ru
} 


\section{SUBTITLE}

Today there are two basic lines of research of corrosion in reinforced concrete bay constructions of motorway bridges. The first is based mainly on the research and generalization of operating experience of reinforced concrete bridges, the analysis of their deterioration patterns and assessment of residual durability and endurance of various structural elements, and creation of corresponding theoretical and empirical dependences. This research line is presented by Vasilyev A.I.; Podvalnij A.M., Shesterikov V.I., Antropova E.A., Bondarenko V.M., Iosilevsky L.I., Chirkov V. P. and some others. The second trend uses probabilistic approach to degradation processes in relation to specific constructions. The followers of this trend are Anisimov A.V.; Shilin A.A.;Zaitsev M.V.; and Zolotareva I.A., who analyze concrete carbonization and chlorides diffusion taking into account climatic and seasonal aggressive impacts on building structures from probabilistic viewpoint.

In the majority of cases reinforced concrete bridges lose their performance characteristics because of corrosion in their concrete reinforcement elements. As a rule corrosion in bridges and overpasses is caused by two concurrent processes:

a) carbonization of concrete cover;

б) deterioration of reinforcement elements due to the ingress of chlorides, mostly sodium chloride, that is traditionally used as an anti-icing agent.

Carbonization of the concrete cover is the most common universal aggressive effect in reinforced concrete structures that are used in natural environment. Essentially this is the process when carbon dioxide, which is contained in the atmosphere in an average volume concentration of $\mathrm{C}=0.03 \%$, interacts with slaked lime and alkali hydroxides of the concrete cover. As a result the $\mathrm{pH}$ value of the concrete liquid phase drops down to 11.0 and more, when in the absence of carbonization it ranges between 12.413.0. Thus the concrete cover can no longer function as an electrochemical protection of reinforcement elements, so the passive state of steel is broken and the reinforcement gets affected by corrosion. The process of such change in the chemical composition of concrete is also called carbonization or neutralization.

Carbonization can be written in the form of the following chemical reaction

$$
\mathrm{Ca}(\mathrm{OH})_{2}+\mathrm{CO}_{2}=\mathrm{CaCO}_{3}+\mathrm{H}_{2} \mathrm{O}
$$

The process is quantitatively rigorously described by simultaneous differential equations [1], that can be simplified to the differential equation of the 1st order known as the 1st Fick's law. Its solution contains empirical parameters which are characterized by uncertainty and spread in values, therefore for the purpose of practical calculations the semi empirical dependence received on the basis of the 1st Fick's law is usually used

$$
\mathrm{X}=\mathrm{A} \sqrt{\tau_{x}}
$$

$\mathrm{X}$ - depth (thickness) of a carbonized layer $(\mathrm{cm}) ; \tau$ - time (years);

A - empirical coefficient $\left(\mathrm{cm} /\right.$ year $\left.^{0,5}\right)$.

The formula (2) has numerous experimental proofs.

If we deal with the structures operating in natural environment, the coefficient (A) reflects a cumulative influence of operating conditions, the position of reinforcing 
Contemporary achievements in civil engineering 23-24. April 2019. Subotica, SERBIA

element in a structure, and climate and weather factors on the carbonization rate and concrete structure.

By analyzing the concrete cover carbonization process in reinforced concrete structures with due consideration of empiric statistical parameters of this process and statistical characteristics of concrete cover thickness it is possible to carry out rational valuation of concrete cover thickness and its design for different elements of reinforced concrete bridges, as well as to estimate the time to the beginning of reinforcement corrosion in operating building structures.

Table1. Recommendations on the maximum content of chlorides in various strucutres

\begin{tabular}{|c|l|c|c|}
\hline \multirow{2}{*}{ № } & \multicolumn{1}{|c|}{ Structure description } & $\begin{array}{c}\text { Construction } \\
\text { class by } \\
\text { content of } \mathrm{Cl}^{-}\end{array}$ & $\begin{array}{c}\text { Maximum } \\
\text { permissible } \\
\text { contents } \mathrm{Cl}^{-} \% \text { per } \\
\text { cement mass }\end{array}$ \\
\hline \multirow{2}{*}{2} & $\begin{array}{l}\text { Non- reinforced concrete without any } \\
\text { metal elements }\end{array}$ & 1.0 & 1.0 \\
\hline 3 & Concrete with regular reinforcement & 0.20 & 0.20 \\
& elements or with metal elements & 0.40 & 0.40 \\
\hline & Prestressed concrete & 0.10 & 0.10 \\
& \multicolumn{2}{|c|}{0.20} & 0.20 \\
\hline
\end{tabular}

Steel reinforcement corrosion resulting from extensive application of chloride salts anti-icers in winter periods is the main reason of reduced life-time of reinforced concrete motorway bridges.

The assessment of corrosive wear of reinforcing elements in a reinforced concrete structure is a serious challenge, because corrosive wear is the parameter that largely determines the state of load-bearing capacity of a building structure, and, hence, has significant influence on administrative decision making issues like setting up maintenance time and scope, evaluating the need in the replacement of failed elements, or the demand to introduce traffic restriction or suspension for repairs period, etc.

The rate of reinforcement corrosion can be accurately determined only by taking samples of reinforcing bars to be studied in laboratory conditions by applying such methods as etching treatment in inhibited acid to find weight loss by comparing actual measurements with reference values. In this case, considering uneven character of corrosion patterns, any reliable data can be obtained only if mathematical statistics requirements are met, i.e. the number of samples should be not less than 10-15.

Meanwhile, the loss of integrity of at least one reinforcement bar leads to a noticeable loss in the bearing capacity of a reinforced concrete structure and for this reason is unacceptable as such.

The assessment of corrosion rate by direct measurements of open reinforcement elements during inspections cannot provide any reliable results, because such shear 
Савремена достигнућа у грађевинарству 23-24. април 2019. Суботица, СРБИЈА

ruptures are often few and it is hardly possible to make any exact measurements on them.

Therefore an assessment technique has been developed by means of which it is possible to determine reinforcement corrosion rate indirectly by assessing its external manifestation effects on the surface of a building structure. It is believed that reinforcement corrosion is manifested by the width of a longitudinal crack opening on the concrete cover surface.

It was found that deformation (displacement) of the concrete cover that is forced out by a corrosive reinforcing bar is:

where $\Delta-$ is corrosion rate

$$
\mathrm{f}=2 \Delta
$$

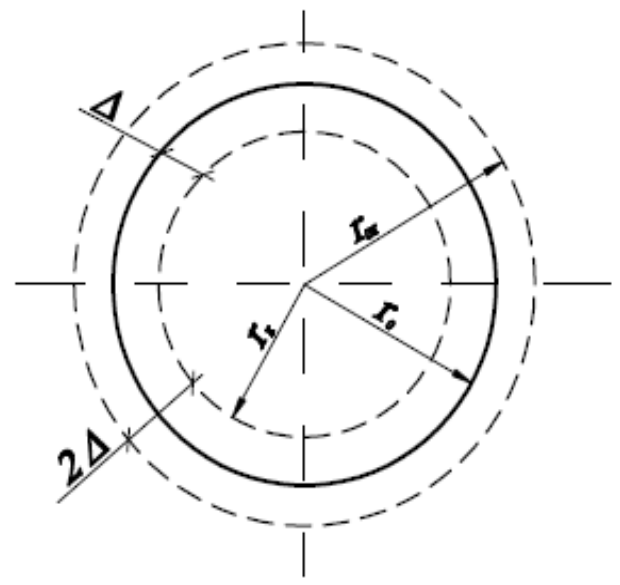

Figure 1. Change in the reinforcing bar section view as a result of corrosion

$r_{\mathrm{o}}$ initial radius of the reinforcing bar section; $\mathrm{r}_{\mathrm{oK}}-$ external radius of the oxide layer; $\mathrm{r}_{\mathrm{K}}$ - radius of a reinforcing bar section resulting from corrosive wear.

If a crack in a structure is formed as a result of concrete over carbonization, then only preventive measures can be taken, such as painting or integral waterproofing treatment of concrete, or elimination of local moisture sources, etc. In case of chloride aggression these measures are insufficient. [2]

A full-size experimental studies on reinforced concrete failures caused by reinforcement corrosion were performed in the Institute of Construction Sciences, Madrid, under the leadership of a famous researcher Prof. C. Andrade.

Steel bars were placed into a concrete sample with a concrete cover thickness of $h=30$ $\mathrm{mm}$; then direct anode current was supplied onto the bars, which caused steel corrosion. Then the dependency between the opening width of a longitudinal crack in the concrete cover and the bar corrosive wear was found. For this purpose the bars were extracted from the sample, etched and weighed to find the weight drop due to corrosion.

The conclusions drawn by authors of this work agree with the findings received in the above studies [3]

The received results weakly depend on the nature of reinforcement and are stable in this sense. Actually they also do not depend on concrete strength as for usual bridge 
Contemporary achievements in civil engineering 23-24. April 2019. Subotica, SERBIA

concretes of $\mathrm{B} 30 \ldots . \mathrm{B} 40$ classes $\mathrm{Rbt} / \mathrm{E} \approx$ const. At the same time the reduced thickness of the concrete cover speeds up its destruction as is observed at inspections.

In this way the research confirms the possibility to assess corrosive wear of reinforcement in the surveyed beams of bridge bay structures without ripping the surface cover off on an extensive area.

Another major factor to be considered in the studies of reinforced concrete simple span bridges is their durability.

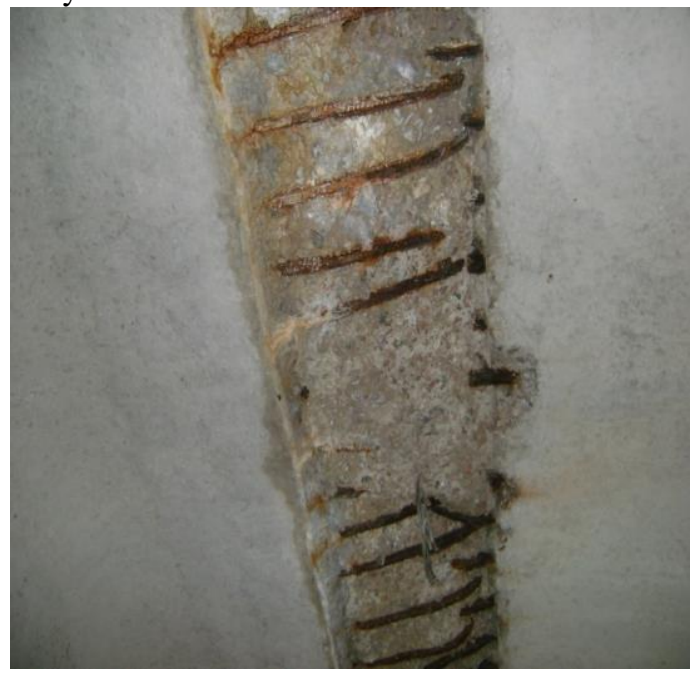

Figure 2. Concrete carbonization and reinforcement corrosion in the concrete cover of a beams joint

The most widespread methods of forecasting the life-time of bridge structures are the methods based on the reliability theory. They are based on the methods of calculating the reliability of building structures developed by V.V. Bolotin and A.R. Rzhanitsyn. Potapkin A.A. [4] focused his studies on the assessment of the service life of bridges considering existing defects and damages. V.I. Shesterikov suggested that the engineering condition of the most busy motorway bridges should be assessed by the criterion of their physical wear, which was considered in [5, 6]. Unlike other approaches the condition of a bridge here is assessed by elements with starting from the surface and down to load bearing structures (decking, slabs and supports). The elements were used to find an overall wear index as the sum of individual wear values taken with their significance factors.

The wear of the span structure is determined as a decrease in its loading capacity, and wear of the beam of the span structure is found as a decrease in its load bearing capacity. The wear of a beam should be found with all registered defects considered. Basically these are the defects caused by the destruction of concrete and reinforcement materials. The most significant items are reduced density and durability of concrete, reduction in the beam rigidity because of peeling and destruction of a protective layer, development of cracks in concrete, and corrosion of reinforcement. All these factors can be determined rather precisely by direct inspections of a facility and used as a basis for further calculations of the actual bearing capacity of a beam.

Corrosion damages of concrete and reinforcement of bridge structures were investigated at a reinforced concrete simple span bridge over the Rogozna River near Starkovo 


\section{7. МЕЂУНАРОДНА КОНФЕРЕНЦИЈА}

Савремена достигнућа у грађевинарству 23-24. април 2019. Суботица, СРБИЈА

village in Kursk Region, Russia. The bridge was chosen as an example object because of multiple defects and overall poor condition. Load bearing capacity calculations were done for the following structures:

- slab span structure; and

- ribbed span structure.

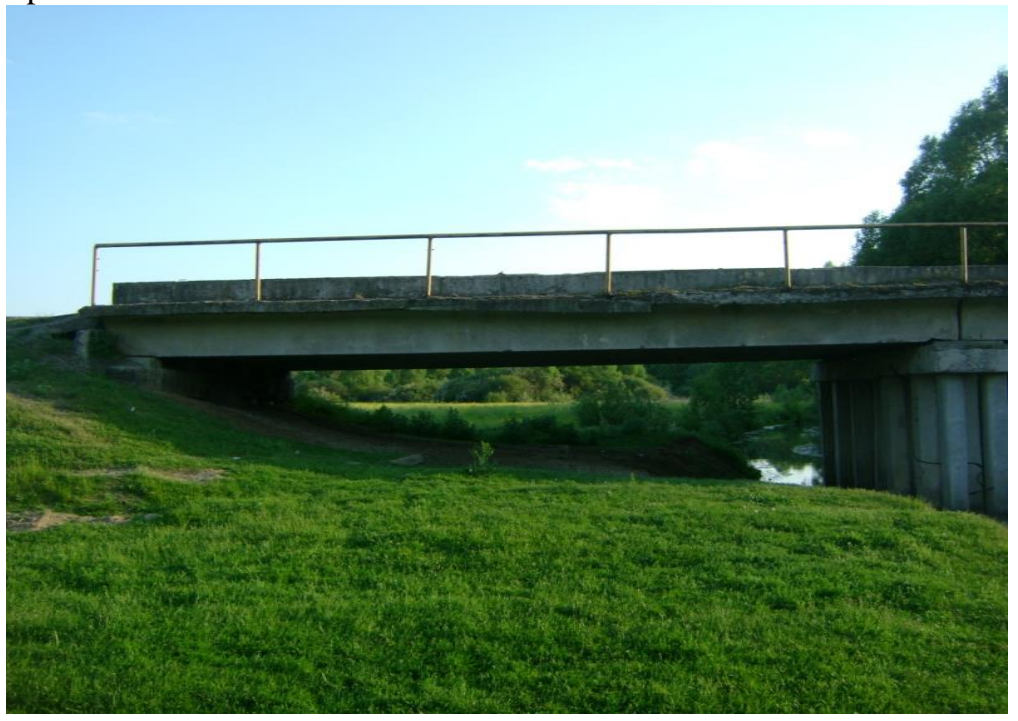

Figure 3. Simple slab reinforced concrete bridge over the Rogozna River near Starkovo viliage, Kursk Region

These are the photos of defects and damages in this bridge structures.

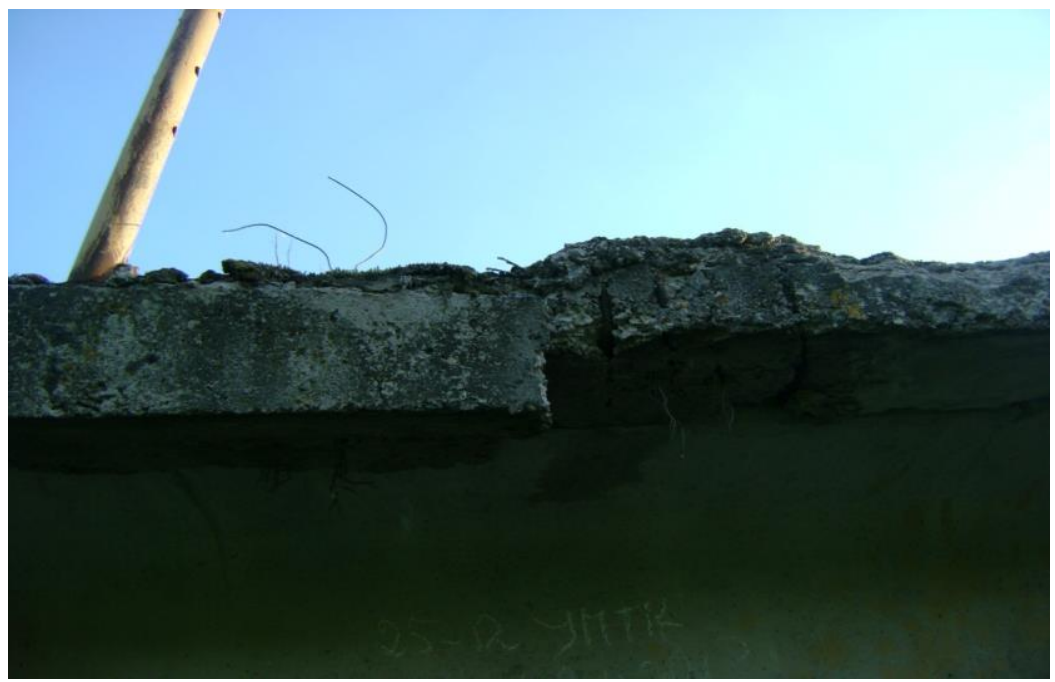

Figure 4. Structural damage of a reinforced concrete slab in the roadway of the bridge, face view 
$7^{\text {th }}$

INTERNATIONAL CONFERENCE

Contemporary achievements in civil engineering 23-24. April 2019. Subotica, SERBIA

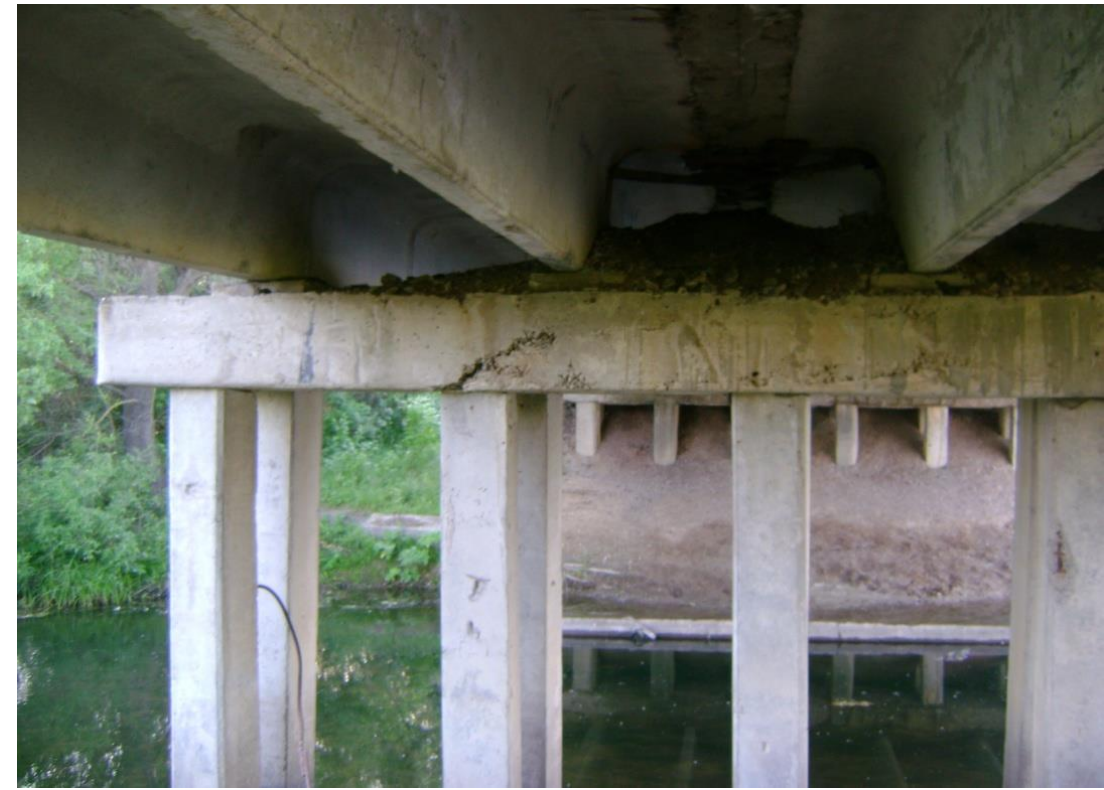

Figure 5. Clearance box. Diagonal cracks in the crossbar.

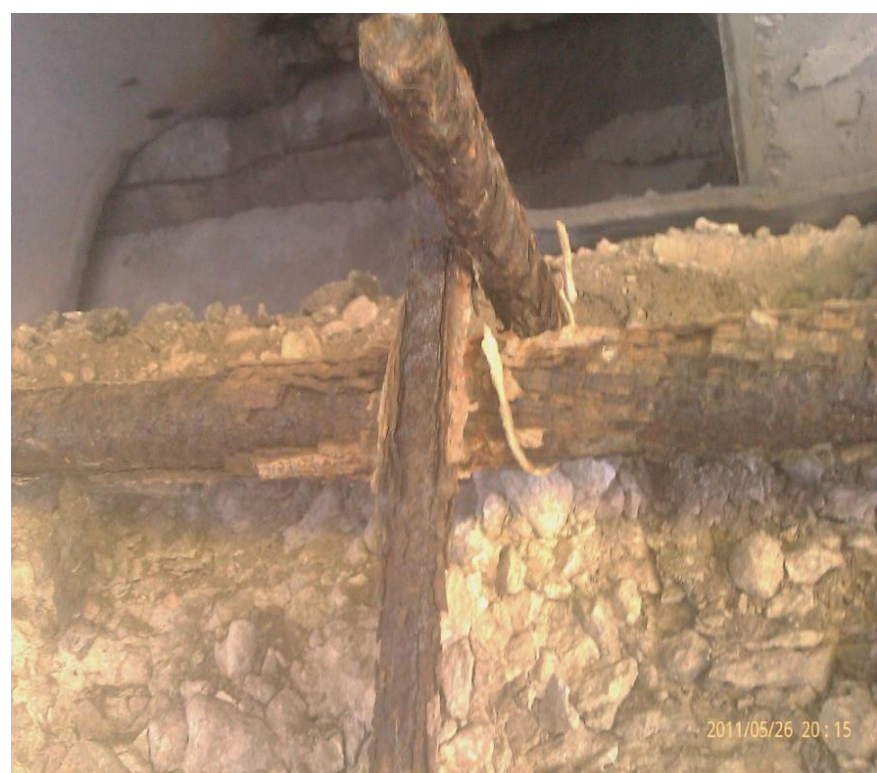

Figure 6. Destruction of concrete with reinforcement exposure and corrosion in the crossbar 
Савремена достигнућа у грађевинарству 23-24. април 2019. Суботица, СРБИЈА

The studies have shown that the reinforced concrete bridge over the Rogozna River at Starkovo needs immediate major repairs and renovation in order to restore its normal working condition.

\section{CONCLUSION}

The research confirms available statistical data and previous scientific findings related with the corrosion studies of reinforced concrete structures of simple span bridges.

\section{REFERENCES}

[1] Дельмон Б. Кинетика гетерогенных реакций. М., 1972.-554 с.

[2] Васильев А.И. Оченка коррозионного износа рабочей арматуры в балках пролетных строений автодорожных мостов. М.: Бетон и железобетон, 2000.

[3] Andrade, C., Alonso, C. Rodriguez, J. ve Garcia, M., "Cover Cracking and amount of Rebar Corrosion : Importance of the Current Applied Accelerated Tests" Concrete Repair, Rehabilitation and Protection E and FN Spon, London, 1996. - P. 263-273

[4] Потапкин А.А. Оченка ресурсов мостов с учётом дефектов и повреждений. М.: Вестник мостостроения, 1997.-С. 22-23.

[5] Иосилевский Л.И. $O$ прогнозировании долговечности мостовых железобетонных конструкиий. М.: Транспортное строительство, 1973.- с. 41-43.

[6] Методика расчетного прогнозирования срока службы железобетонных пролетных строений автодорожных мостов. М., 2001.-128 c. 